\title{
E3 Ubiquitin-Protein Ligase RNF130
}

National Cancer Institute

\section{Source}

National Cancer Institute. E3 Ubiquitin-Protein Ligase RNF130. NCI Thesaurus. Code C111933.

E3 ubiquitin-protein ligase RNF130 (419 aa, $46 \mathrm{kDa}$ ) is encoded by the human RNF130 gene. This protein is involved in post-translational protein ubiquitination. 